\title{
The Effect of Knowledge Sharing Using Customer Relationship Management Systems in Manufacturing Companies
}

\author{
Justyna PATALAS-MALISZEWSKA, Sławomir KŁOS
}

\begin{abstract}
This study assesses the influence on knowledge sharing among workers within Polish manufacturing enterprises. The study focuses on those workers who are involved within a company in a New Product Development (NPD) Process and who share their knowledge using the Customer Relationship Management (CRM) systems. The outcome based on the data obtained from Polish enterprises suggests that the use of the following functionalities of CRM system by workers: the Customer Profitability Database, the daily/weekly/monthly Customer Contact Database and the Customer Requirement Database focusing on services, affects knowledge sharing and increase the creation of new products. This case study investigates how useful that knowledge is which has been achieved using CRM systems and it clarifies its effect in Polish manufacturing enterprises.
\end{abstract}

Keywords: Creation of New Products; Knowledge Sharing; Polish Manufacturing Company

\section{INTRODUCTION}

Knowledge, in a company, affords a certain competitive advantage to that company [1-3]. Due to its very nature, tacit and explicit knowledge can be distinguished [4]. Explicit knowledge is identified from data and information in the knowledge base [5], it is formalised and can be presented by means of verbal communication, technical documentation, instructions or diagrams. Tacit knowledge, however, is assigned to a given employee and is associated with his/her education, experience and abilities [6]. Knowledge sharing between workers, both tacit and explicit, is a principal problem when managing the development of a new product in a company [7]. Knowledge sharing is treated as the knowhow to collaborate with other workers in order to develop new ideas [8]. Knowledge can be shared by the worker(s) with his/her/their recipients by using different tools. The customer relationship management system supports providing services for customers [9]. It is the information system that enables organisations to receive complete data and information of customers [10]. CRM system supports knowledge externalization process [11] and can be a useful tool in supporting the explicit and tacit knowledge sharing process in order to increase the creation of new products in a company.

This study, based on the data received from Polish manufacturing enterprises, presents the impact of knowledge sharing among workers who are involved in a New Product Development (NPD) Process using a CRM system on an increasing number of new products within a company.

\section{RESEARCH MODEL}

The process of New Product Development (NPD) is realized in accordance with the enterprise's needs [12]. Based on the literature study [13]; [14]; [15]; [16]; [17] in this work, three dimensions of a NPD process in a manufacturing enterprise are formulated: (1) an innovative environment, (2) the process of product development, (3) communication within a company (team cooperation).

\section{(1) An innovative environment}

The results of an analysis of the level of innovation in Europe, that were published by the European Commission [18], show that Poland is still a country with a very low innovation performance (Poland belongs to a group known as moderate innovators). On the basis of the indicators, included in this report, the factors that describe an innovative environment in the development of a new product in a manufacturing enterprise are formulated:

- IE1 - the value of expenditure on innovation activities in industrial enterprises in Poland (in thousand PLN/year),

- IE2 - the share of companies that cooperate in the field of innovative activities of all enterprises in Poland (in $\%)$,

- IE3 - the share of sales of new/improved products of industrial enterprises in the sales value of total products in industrial enterprises in Poland (in \%),

- IE4 - the share of income from sales of innovative products in industrial enterprises in the value of total income in industrial enterprises in Poland (in \%),

- IE5 - the number of patents,

- IE6 - the value of internal expenditure on R\&D in enterprises in Poland (in thousand PLN/year),

- IE7 - the value of external expenditure on R\&D in enterprises in Poland (in thousand PLN/year),

- IE8 - the number of employees in R\&D in enterprises in Poland (in FTE/year).

\section{(2) The process of product development}

Not only do the workers design a new product, but they also define the process of the development of the product according to the innovation protocols of the manufacturing company in which they work. In the literature, seven dimensions of the NPD process are defined $[19,20]$ :

- D1 - defining the strategy in the company,

- D2 - conducting the research,

- D3 - commercialization,

- D4 - implementing the new product,

- D5 - company innovation climate,

- D6 - company culture,

- D7 - a project of reporting product development. 
Based on the results of the literature study, it is possible to define the activities associated with the dimensions of the NPD process in a manufacturing company [7]:

- for D1 - elaboration of the idea for a new product,

- for D2 - elaboration of the specification of a new product; performing a preliminary design of a new product; performing a detailed design of a new product; engineering simulation; generating a prototype; testing a new product,

- for D3- commercialising a new product,

- for D4 - economic analysis of a new product; risk analysis of a new product; preparing the production process; manufacturing simulation,

- for D5 - starting the production of a new product,

- for D6 - service for a new product; cooperation with suppliers,

- $\quad$ for D7 - investment analysis of a new product.

\section{(3) Communication (team cooperation)}

Knowledge sharing in a manufacturing enterprise is treated as communication among employees by which one worker can help to transmit the knowledge to another [21] using different tools. CRM system is used to support the knowledge sharing among employees.

CRM systems are used to support Customer Services departments and the sale and marketing activities of a company. In our case study, we analyse whether the workers actually share their knowledge using the chosen functionalities of CRM systems and, if so, whether this influences the increase in new products in a company. We state that employee knowledge involves the NPD process; this should be shared since it is created, thanks to the use of customer databases in the CRM system. For this reason, we distinguish databases that are in the CRM system. The research concerns the indication of CRM functionality, which enables knowledge sharing and has an impact on the increase in the creation of new products.

So, it is possible to define the following functionalities of CRM systems used in manufacturing companies:

- Customer Profitability Database (DCP),

- daily/weekly/monthly Customer Contact Database (DCC),

- Offered Products Database (DOP),

- Customer Contracts Database (DCN),

- Customer Segmentation Database (CS),

- Customer Reports Database (DRC),

- Automated Workflow and Information (AWI),

- Customer Support Database (DSEC),

- Meetings with clients Database (DSC),

- database of the time of all realized support for clients (DTSC),

- database of costs of each realized instance of support for clients (DCSC),

- database of reports of all realized support for clients (DRSC),

- Customer Requirement Database(DCD),

- Customer Requirement Database: focus on service (DCDS).

This study assumes that communication among workers within a company in a new product development process is realized using CRM system (Fig. 1).

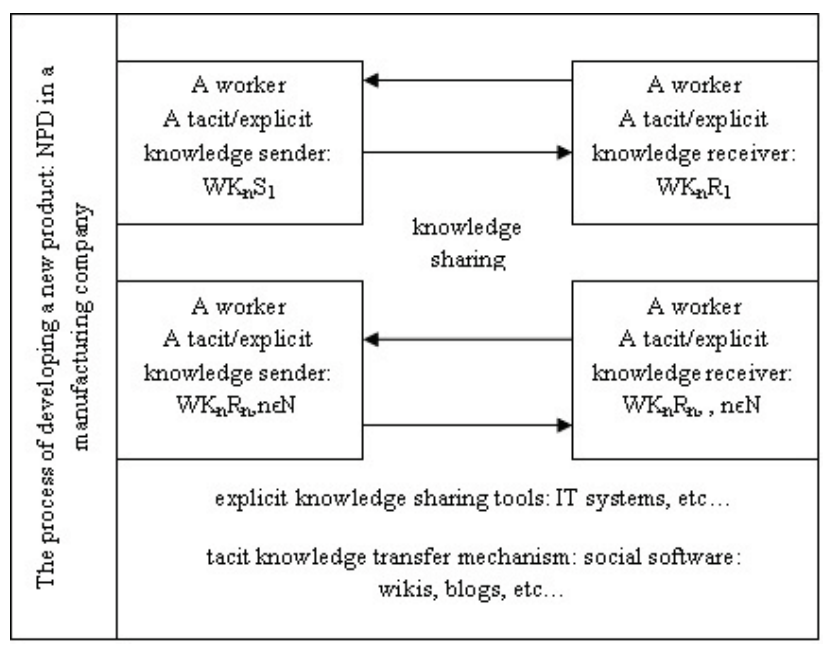

Figure 1 Communication within company in a new product development process: knowledge sharing

This article offers an explanation of the influence of knowledge sharing among workers applying CRM system on increase of the creation of new products.

This study assumes also that those workers who were involved in the survey realize at least $80 \%$ of the defined activities associated with the dimensions of the NPD process and adopt the defined functionalities of a CRM system to realize this process.

Moreover, a strict innovative environment was defined for all the companies, which were involved in the survey [22]:

- IE1 - the value of expenditure on innovation activities in industrial enterprises in Poland (in thousand PLN/2013): 20,958,946 thousand PLN,

- IE2 - the share of companies that cooperate in the field of innovative activities of all total enterprises in Poland (in \%, in 2013): $5.2 \%$,

- IE3 - the share of sales of new / improved products of industrial enterprises in the sales value of total products in industrial enterprises in Poland (in \%, in 2013): $11.47 \%$,

- IE4 - the share of income from sales of innovative products in industrial enterprises in the value of the total income of industrial enterprises in Poland (in \%, in 2013): $8.65 \%$,

- $\quad$ IE5 - the number of patents (2013): 2339,

- IE6 - the value of internal expenditure on R\&D in enterprises in Poland (in thousand PLN/2012): 5,341,000.1 thousand PLN,

- $\quad$ IE7 - the value of external expenditure on R\&D in enterprises in Poland (in thousand PLN/2012): 2,086,640.1 thousand PLN,

- $\quad$ IE8 - the number of employees in R\&D in enterprises in Poland (in EPC/2013): 25,750.

The results of the analysis of the level of innovation of industrial enterprises in Poland, published by the Central Statistical Office of Poland, indicated that Polish manufacturing companies are still not innovative enough.

Therefore, this article establishes that knowledge sharing among worker in enterprises, applying CRM systems, will have positive impact on the NPD process (see first hypothesis). 
H1. Knowledge sharing among workers applying CRM systems while involved in the NPD process in order to increase the number of new products in Polish manufacturing companies.

According to the chosen functionalities of a CRM system the first hypothesis is extended to 14 subhypotheses (Fig. 2).

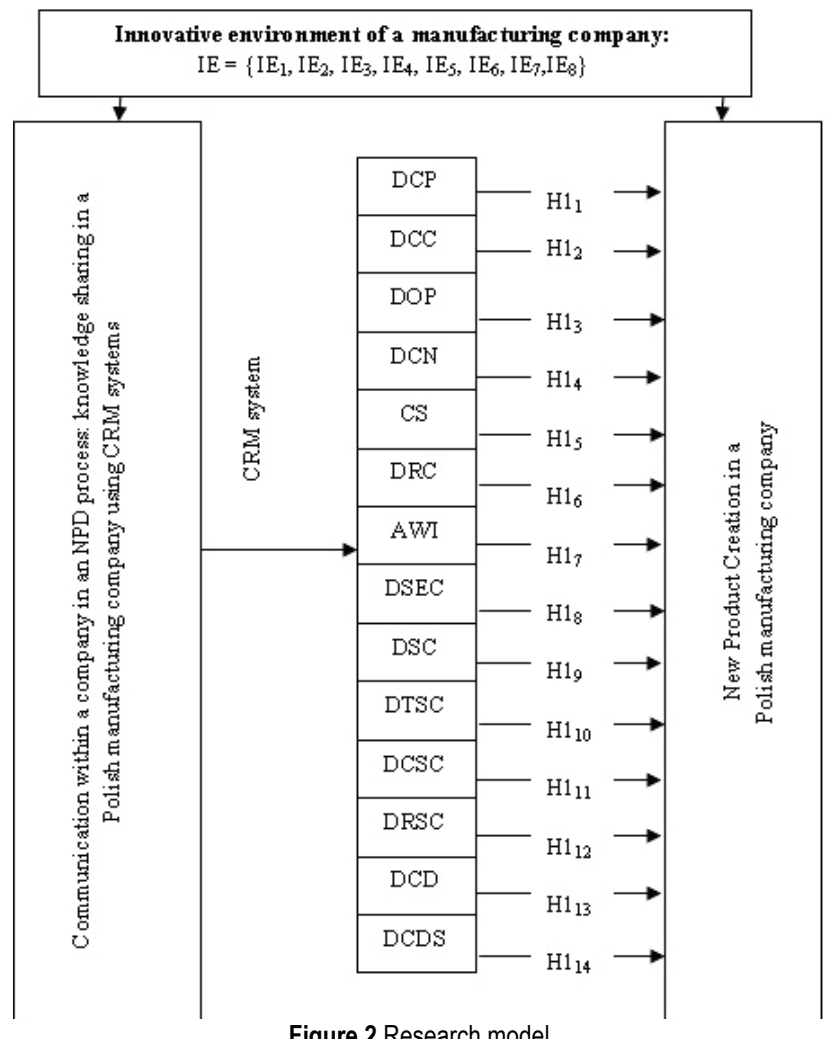

The surveys applied for testing the model (Fig. 2) were developed by defining scales to fit the knowledge codification meaning. Factors of new product creation in enterprises and of the use of a CRM system were based on feedback surveys and their sources are listed here:

- The use of a CRM system: I know that in my company the realization of the work activities using CRM, namely the functionality: Customer Profitability Database (DCP)/daily/weekly/monthly Customer Contact Database (DCC)/ Offered Products Database (DOP)/Customer Contracts Database (DCN)/ Customer Segmentation Database (CS)/Customer Reports Database (DRC)/Automated Workflow and Information (AWI)/Customer Support Database (DSEC)/Meetings with clients Database (DSC)/ database of the time of all realized support for clients (DTSC)/database of costs of each realized instance of support for clients (DCSC)/database of reports of all realized support for clients (DRSC)/Customer Requirement Database (DCD)/Customer Requirement Database: focus on service (DCDS).

is: factor1: not very important/ factor2: not important/ factor3: quite important/ factor4: important/ factor5: very important for knowledge sharing

- New product creation: I know that in my organization the realization of the work activities using CRM, namely the functionality: Customer Profitability
Database (DCP)/daily/weekly/monthly Customer Contact Database (DCC)/ Offered Products Database (DOP)/Customer Contracts Database (DCN)/ Customer Segmentation Database (CS)/Customer Reports Database (DRC)/Automated Workflow and Information (AWI)/Customer Support Database (DSEC)/Meetings with clients Database (DSC)/ database of the time of all realized support for clients (DTSC)/database of costs of each realized instance of support for clients (DCSC)/database of reports of all realized support for clients (DRSC)/Customer Requirement Database (DCD)/Customer Requirement Database: focus on service (DCDS) is: factor1: not very important/ factor2: not important/ factor3: quite important/ factor4: important/ factor5: very important for New Product Creation.

A five-point scale was adopted for all survey research items. The data for this study were collected from 25 Polish manufacturing enterprises between April to May, 2014 (see Tab. 1):

Table 1 Table Profile of enterprises and respondents

\begin{tabular}{|c|c|c|}
\hline \multirow{3}{*}{ Industry } & Items & $\begin{array}{c}\text { Frequency } \\
(N=25)\end{array}$ \\
\hline \multirow{3}{*}{} & Construction & $20(80 \%)$ \\
\cline { 2 - 3 } & Metallurgy & $1(4 \%)$ \\
\cline { 2 - 3 } & Chemical & $1(4 \%)$ \\
\cline { 2 - 3 } & Others & $3(12 \%)$ \\
\hline \multirow{2}{*}{ Division of the enterprise } & Research and Development & $20(80 \%)$ \\
\cline { 2 - 3 } & Management & $5(20 \%)$ \\
\hline
\end{tabular}

\section{THE INFLUENCE OF KNOWLEDGE SHARING ON THE INCREASE OF THE NUMBER OF NEW PRODUCTS}

The research model (Fig. 2) was studied using a correlation and regression approach in order to estimate the impact of using CRM systems as tool to support knowledge sharing among workers in Polish manufacturing enterprises. A moderated correlation approach, using Statistica ver.10.0, was applied to test the defined hypothesis. The data were carefully examined with respect to linearity, equality of variance and normality. No significant deviations were detected. Table 2 presents correlations analysis.

Tab. 2 presents the results of the correlation analyses which estimate the impact of knowledge sharing in Polish manufacturing enterprises using CRM systems in the defined innovative environment, as well as their interaction on New Product Development Process in a company. The primary interaction of using CRM systems, such as a knowledge-sharing support tool, makes a meaningful contribution to New Product Creation, namely: the Customer Profitability Database $($ corr $=0.6122)$. The second interaction of CRM usage is also meaningful and makes a discernible contribution to the process of New Product Creation, namely: the daily/weekly/monthly Customer Contact Database $($ corr $=-0.6592)$. The third interaction of CRM system usage makes a significant contribution to New Product Creation, namely: the Customer Requirement Database: focus on services (corr $=0.4367$ ).

To define the nature of significant interactions of knowledge sharing in Polish manufacturing enterprises 
among workers, who realize an NPD process applying CRM systems and carry out New Product Creation in a defined innovative environment, the study tests the hypotheses using regression analyses, which estimate this impact.

Table 2 Correlations analysis

\begin{tabular}{|c|c|c|c|c|}
\hline Construct & Correlation & $R^{2}$ & $t$ & $p$ \\
\hline Customer Profitability Database (DCP)/NPD & 0.6122 & 0.3748 & 3.6316 & 0.0014 \\
\hline daily/weekly/monthly Customer Contact Database (DCC)/NPD & 0.6592 & 0.4345 & 4.1121 & 0.0005 \\
\hline Offered Products Database (DOP)/NPD & 0.2466 & 0.0608 & 1.1935 & 0.2453 \\
\hline Customer Contracts Database (DCN)/NPD & 0.0801 & 0.0064 & 0.3769 & 0.7097 \\
\hline Customer Segmentation Database (CS)/NPD & -0.3996 & 0.1596 & -2.0446 & 0.0530 \\
\hline Customer Reports Database (DRC)/NPD & -0.0741 & 0.0054 & -0.3487 & 0.7306 \\
\hline Automated Workflow and Information (AWI)/NPD & 0.1325 & 0.0175 & 0.62736 & 0.5368 \\
\hline Customer Support Database (DSEC)/NPD & -0.0470 & 0.0022 & -0.2211 & 0.8270 \\
\hline Meetings with clients Database (DSC)/NPD & 0.0853 & 0.0072 & 0.4016 & 0.6917 \\
\hline Database of the time of all realized support for clients (DTSC)/NPD & 0.0411 & 0.0016 & 0.1930 & 0.8486 \\
\hline Database of costs of each realized instance of support for clients (DCSC) /NPD & -0.0385 & 0.0014 & -0.1809 & 0.8580 \\
\hline Database of reports of all realized support for clients (DRSC)/NPD & 0.2372 & 0.0562 & 1.1454 & 0.2643 \\
\hline Customer Requirement Database (DCD)/NPD & -0.3459 & 0.1196 & -1.7295 & 0.0977 \\
\hline Customer Requirement Database: focus on service (DCDS)/NPD & 0.4367 & 0.1907 & 2.2768 & 0.0328 \\
\hline
\end{tabular}

To define the nature of the first meaningful interaction: the database of customer profitability and New Product Creation, the study presents the impact (see Fig. 3) as a result of using a database of customer profitability to share knowledge within a manufacturing company.

$$
\text { New Product Creation }=0.6531 D C P+0.4052
$$

The number of new products increases with a higher frequency of use of CRM system within a company, namely: Customer Profitability Database. When given rare frequencies of using the database of customer profitability, a decrease in company New Product Creation is clear. So, the hypothesis $\mathrm{H} 1_{1}$ is confirmed.

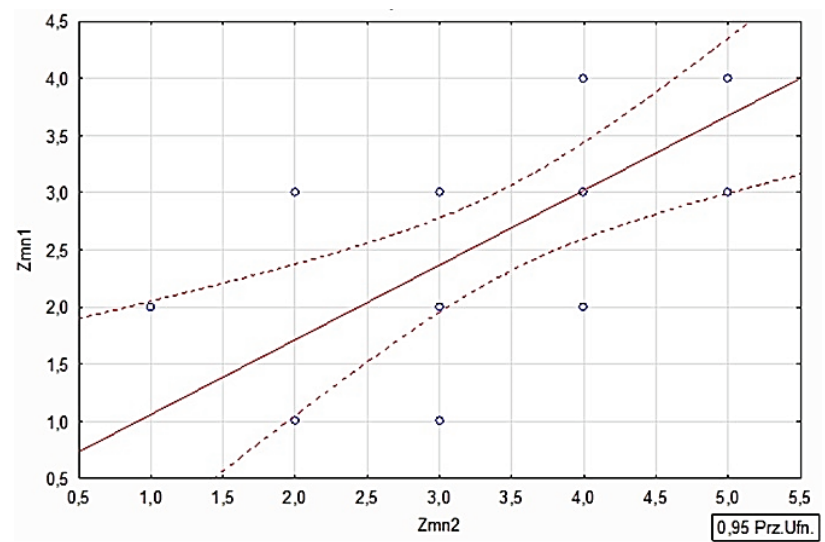

Figure 3 Relationship between New Product Creation and knowledge sharing using a database of customer profitability DCP

For $\mathrm{H}_{2}$, we examine the relationship between knowledge sharing among workers using a database of daily/weekly/monthly contact with customers 1 and New Product Creation. As Tab. 2 and Fig. 4 show, the impact of knowledge sharing on New Product Creation has a value of 0.6592 and is statistically meaningful, and thus provides support for $\mathrm{H}_{2}$. To determine the nature of this significant connection, the study presents the impact (see Fig. 4)

New Product Creation $=0.6364 D C C+0.5455$

The creation of a new product within a company increases with knowledge sharing when workers use CRM system, namely: daily/weekly/monthly Customer Contact Database.

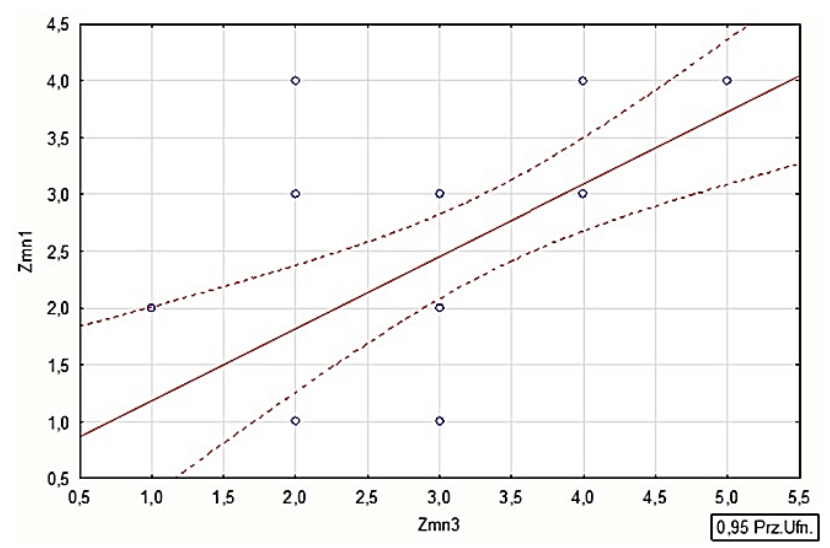

Figure 4 Connections between New Product Creation and knowledge sharing using a database of daily/weekly/monthly contact with customers

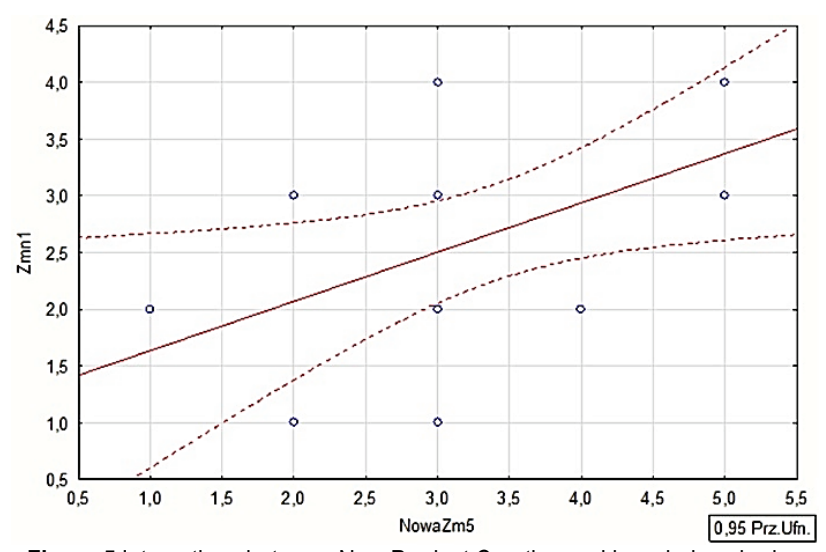

Figure 5 Interactions between New Product Creation and knowledge sharing using a database of customers' needs: focus on services

And for $\mathrm{H}_{14}$, we examined the effects on New Product Creation that result from sharing knowledge using the functionality of a CRM system: the Customer Requirement Database: focus on services. This effect was found to be statistically significant. The study presents the effect (see Fig. 5).

New Product Creation $=0.4344 D C D S+1.2006$ 
The creation of a new product within a company clearly increases with knowledge sharing when its employees realize NPD processes with the use of CRM systems, namely: database of customers' needs: focus on services.

This study does not only testify to the impact of sharing knowledge using a CRM system on NPD processes in manufacturing enterprises, but also explores how it is possible to use the defined functionalities of this system. Fig. 6 presents the structural model.

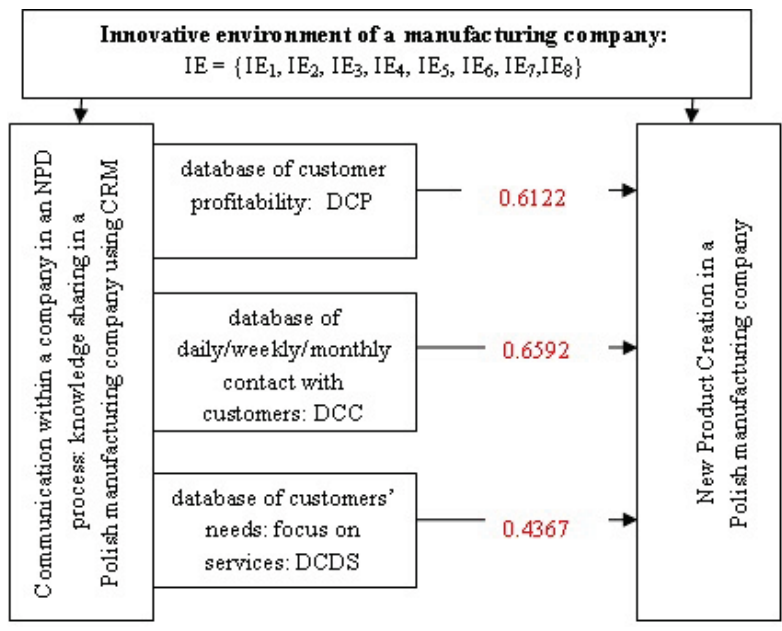

Figure 6 Structural model

This study explores the influence of knowledge sharing on the increase in the number of new products - in the context of Polish Manufacturing Companies - by workers involved in realising the NPD process, using defined functionalities of CRM system. The statistical results showed that the $3 \mathrm{CRM}$ functionalities examined contribute to knowledge sharing and have the strongest positive effect on the creation of new products.

\section{CONCLUSIONS}

According to the research results within Polish manufacturing enterprises, it can be concluded that knowledge sharing among employees involved in NPD process, applying a CRM system, affects the creation of new products.

Employees are capable of creating new knowledge about the most advantageous customer portfolios based on an analysis of the functionality of the CRM system: customer profitability (DCP). This knowledge is created and will be passed on to other employees to identify key customers for the company and will form the basis for building a strategy of relations with key company clients. In turn, this close cooperation with key clients leads to the increase of new products within the company.

The research results also show how strong the impact of knowledge sharing is, as a result of using the functionality of CRM systems: daily/weekly/monthly Customer Contact Database (DCC) to increase the number of new products. It can be concluded that current contacts with clients lead to the creation of knowledge regarding the clients' needs. As a result of knowledge sharing among employees, new solutions are created based on defined customer needs, which leads to the generation of new ideas.

One interesting result is the use of Customer Needs Database focusing on service (DCDS) in order to increase the number of new products. It follows that the more information is gathered about the needs of clients with regard to company services (reports), the more may employees create further ideas for new products thanks to the sharing of knowledge resulting from an analysis of the aforesaid reports; knowledge about the client's needs in the context of the services provided can be the basis for creating new product concepts in a manufacturing company.

The research results confirm the hypotheses. Sharing useful knowledge among employees with assistance from the CRM system can increase the creation of new products in Polish manufacturing companies.

In further research, we will develop our research model for the NPD process supported by another method and/or tools; we will distinguish tacit as opposed to explicit knowledge sharing and their individual influence on the creation of new products.

\section{REFERENCES}

[1] Afsheen, F., Rabia, I., Hina, S. \& Sehar, Z. (2015). Knowledge sharing among Pakistani IT professionals: Examining the role of procedural justice, pay satisfaction and organizational commitment. Advanced Research Letters, 21(5), 1189-1192. https://doi.org/10.1166/asl.2015.6047

[2] Hu, M. L. M., Horng, J. S. \& Sun Y. H. C. (2009). Hospitality teams: Knowledge sharing and service innovation performance. Journal of Tourism Management, 30(1), 41-50. https://doi.org/10.1016/j.tourman.2008.04.009

[3] Yesil, S. \& Dereli, S. F. (2013). An Empirical Investigation of the Organisational Justice, Knowledge Sharing and Innovation Capability. Procedia - Social and Behavioral Sciences, 75(3), 199-208. https://doi.org/10.1016/j.sbspro.2013.04.023

[4] Nonaka, I. \& Takeuchi, H. (2000). Creation of knowledge in the organisation. Warsaw: Poltext.

[5] Patalas-Maliszewska, J. (2013). Knowledge Worker Management: Value Assessment, Methods, and Application Tools. Heidelberg: Springer. https://doi.org/10.1007/978-3-642-36600-0

[6] Nonaka, I. (1994). A dynamic theory of organisational knowledge creation. Organisation science, 5(1), 14-37. https://doi.org/10.1287/orsc.5.1.14

[7] Patalas-Maliszewska, J. \& Kłos, S. (2018). Knowledge Sharing Using Customer Relationship Management Systems (CRM) in NPD Processes - Research Results from Polish and German Manufacturing Companies. Proceedings: Information Systems Architecture and Technology: Proceedings of 38 th International Conference on Information Systems Architecture and Technology - ISAT 2017.

[8] Wang, S. \& Noe, R. A. (2010). Knowledge sharing: A review and directions for future research. Journal of Human Resource Review, 20, 115-13 https://doi.org/10.1016/j.hrmr.2009.10.001

[9] Teo, T. S. H., Devadoss, P. \& Pan, S. L. (2006). Towards a holistic perspective of customer relationship management (CRM) implementation: a case study of the Housing and Development Board, Singapore. Decision Support Systems, 42, 1613-1627. https://doi.org/10.1016/j.dss.2006.01.007

[10] Karakostas, B., Kardaras, D. \& Papathanassiou, E. (2005). The state of CRM adoption by the financial services in the UK: an empirical investigation. Information \& Management, 42, 853-863. https://doi.org/10.1016/j.im.2004.08.006

[11] Khodakarami, F. \& Chan, Y. E. (2014). Exploring the role of customer relationship management (CRM) systems in customer knowledge creation. Information \& Management, 51(1), 27-42. https://doi.org/10.1016/j.im.2013.09.001 
[12] Davidson, J. M., Clamen, A. \& Karol, R. A. (1999). Learning from the best new product developers. Research-Technology Management, 42(4), 12-18. https://doi.org/10.1080/08956308.1999.11671289

[13] Kahn, K. (2005). PDMA handbook of new product development. New York, John Wiley and Sons.

[14] Lester, D. H. (1998). Critical success factors for new product development. Research-Technology Management (RTM) Journal, 41(1), 36-43. https://doi.org/10.1080/08956308.1998.11671182

[15] March-Chorda, I., Gunasekaran, A. \& Lloria-Aramburo, B. (2002). Product development process in Spanish SMEs: an empirical research. Technovation, 22, 301-312. https://doi.org/10.1016/S0166-4972(01)00021-9

[16] Poolton, J. \& Barclay, I. (1998). New product development from past research to future application. Industrial Marketing Management, 27, 197-212. https://doi.org/10.1016/S0019-8501(97)00047-3

[17] Pun, K. F. \& Chin, K. S. (2005). Online assessment of new product development performance: an approach. Total Quality Management \& Business Excellence, 16(2), 157169. https://doi.org/10.1080/14783360500054244

[18] Innovation Union Scoreboard (2014). Retrieved from http://ec.europa.eu/enterprise/policies/innovation/files/ius/i us-2014 en.pdf

[19] Barczak, G., Griffin, A. \& Kahn, K. B. (2009). Trends and drivers of success in NPD practices: Results of the 2003 PDMA best practices study. Journal of Product Innovation Management, 26(1), 3-23. https://doi.org/10.1111/j.1540-5885.2009.00331.x

[20] Cooper, R. G., Edgett, S. J. \& Kleinschmidt, E. J. (2004). Benchmarking best NPD practices. Research-Technology Management, 47(6), 43-55. https://doi.org/10.1080/08956308.2004.11671606

[21] Lin, H. F. (2007). Knowledge sharing and firm innovation capability: An empirical study. International Journal of Manpower, 28, 315-332. https://doi.org/10.1108/01437720710755272

[22] Central Statistical Office of Poland (2013). Retrieved from http://stat.gov.pl/en/

\section{Contact information:}

Justyna PATALAS-MALISZEWSKA, Prof. D.Sc. Eng.

University of Zielona Góra, Mechanical Department,

ul. prof. Z. Szafrana 4,

65-516 Zielona Góra, Poland

J.Patalas@iizp.uz.zgora.pl

Sławomir KŁOS, Prof. D.Sc. Eng.

University of Zielona Góra, Mechanical Department,

ul. prof. Z. Szafrana 4

65-516 Zielona Góra, Poland

S.Klos@iizp.uz.zgora.pl 